\title{
PERSEPSI PENGHUNI TERHADAP KENYAMANAN BERAKTIVITAS DI RUANG TERBUKA PERUMAHAN
}

\author{
Anugerah Septiaman Harefa ${ }^{(1)}$, Polin DR. Naibaho, ST. MT ${ }^{(2)}$, Anna Lucy Rahmawati, ST.MT ${ }^{(3)}$ \\ (1) Mahasiswa, Prodi Arsitektur, Fakultas Teknik, Universitas Katolik Santo Thomas Sumatera Utara \\ (2) Staff Pengajar, Prodi Arsitektur, Fakultas Teknik, Universitas Katolik Santo Thomas Sumatera Utara \\ Email: pakrektor2@gmail.com \\ (3) Staff Pengajar, Prodi Arsitektur, Fakultas Teknik, Universitas Katolik Santo Thomas Sumatera Utara \\ Email: lucyra7011661@gmail.com
}

\begin{abstract}
A comfort open space has a function and a huge influence in housing because it becomes a means of activity throughout the housing dwellers. Debang Housing Taman Sari Medan is one of housing in Kecamatan Medan Selayang which has open space. The purpose of this research is to know the perception of occupant to the comfort of open space. There are several convenience factors that are used as indicators in research such as Circulation, Climate, Noise, Smell, Shape, Safety, Cleanliness, and Beauty. The research was done through qualitative descriptive analysis, where the data collection technique used questionnaire from the population and the specified sample. The process of collecting data, sampling technique until the criteria of research become an important process of research method. This study shows if the perception of occupants of the comfort of open space of housing Debang Taman Sari Medan is quite comfortable and needed supporting facilities for park users.
\end{abstract}

Keywords : Perception, comfort, open space

\begin{abstract}
Abstrak
Kenyamanan ruang terbuka memiliki fungsi dan pengaruh yang sangat besar dalam sebuah perumahan, karena menjadi sarana beraktivitas seluruh penghuni perumahan.Perumahan Debang Taman Sari Medan merupakan salah satu perumahan di Kecamatan Medan Selayang yang memiliki ruang terbuka.Tujuan penelitian adalah untuk mengetahui persepsi penghuni terhadap kenyamanan ruang terbuka perumahan.Ada beberapa faktor kenyamanan yang digunakan sebagai indikator dalam penelitian seperti Sirkulasi, Iklim, Kebisingan, aroma, bentuk, Keamanan, kebersihan dan keindahan.Penelitian dilakukan melalui analisis deskriptif kualitatif, dimana teknik pengumpulan data menggunakan kuisioner dari populasi dan sampel yang telah ditetapkan. Proses pengumpulan data, teknik sampling hingga kriteria penelitian menjadi proses penting metode penelitian. Penelitian ini menunjukkan jika persepsi penghuni terhadap kenyamanan beraktivitas diruang terbuka perumahan Debang Taman Sari Medan yaitu cukup nyaman dan diperlukan sarana penunjang untuk pengguna taman.
\end{abstract}

Kata Kunci:Persepsi, Kenyamanan dan Ruang Terbuka

\section{Pendahuluan}

Beberapa tahun terakhir perkembangan dan perubahan perumahan di Kota Medan cukup pesat.Perkembangan dan perubahan ini juga berpengaruh pada kebutuhan ruang bersosialisasi.Setiap hari manusia melakukan aktivitas di dalam perumahan, baik aktivitas di dalam rumah maupun diluar rumah.Kegiatan atau aktivitas yang dilakukan diluar rumah tentunya membutuhkan sarana yang nyaman untuk beraktivitas seperti ruang terbuka.Sebuah perumahan juga tentunya sangat membutuhkan yang namanya ruang terbuka, walaupun diantara perumahan di Kecamatan Medan Selayang tidak semua memiliki ruang terbuka.

Perumahan Debang Taman Sari merupakan salah satu perumahan yang termasuk dalam komunitas berpagar di Kecamatan Medan Selayang.Di dalam perumahan Debang Taman Sari Medan terdapat ruang terbuka dan merupakan salah satu perumahan yang memiliki ruang terbuka diantara perumahan lain di Kecamatan Medan Selayang.

Bersosialisasi dan beraktivitas merupakan suatu aktivitas sosial manusia yang tidak bisa dihindarkan didalam perumahan, sehingga perlu diatur suatu tempat untuk mewadahi aktivitas tersebut sehingga dapat menciptakan perumahan yang nyaman dinikmati oleh penghuni perumahan.Pada kawasan Perumahan Debang Taman Sari sendiri, terdapat beberapa ruang terbuka yang pada umumnya digunakan untuk beraktivitas. Akan tetapi, diruang terbuka 
perumahan debang taman sari lebih sering terlihat tidak ramai pada jam tertentu. Ruang terbuka yang seharusnya diperuntukkan bagi masyarakat perumahan telah beralih fungsi menjadi tempat-tempat yang tidak terurus, kemudian menjadi tempat meletakkan benda-benda bekas didalam perumahan serta tumbuhan menjalar yang tumbuh tidak pada tempat yang seharusnya.Ruang terbuka di dalam Perumahan Debang Taman Sari adalah salah satu contoh ruang terbuka yang terdapat didalam perumahan di Medan Selayang, yang hampir setiap hari selalu dilewati oleh masyarakat yang tinggal di dalam perumahan tersebut.Dengan beberapa contoh fenomena yang terjadi di dalam perumahan tersebut, membuat peneliti merasa tertarik untuk mengetahui presepsi penghuni terhadap kenyamanan beraktivitas diruang terbuka perumahan.

\section{Landasan Teori}

\section{Kenyamanan}

Kenyamanan dan perasaan nyaman adalah penilaian komprehensif seseorang terhadap lingkungannya.Faktorfaktor yang mempengaruhikenyamanan adalah sebagai berikut:

\section{a. Sirkulasi}

Jalan sebagai prasarana lalu lintas berfungsi juga sebagai ruang terbuka untuk kontak sosial, wadah kegiatan, vegetasi, dan aktivitas perekonomian masyarakat. Kenyamanan dapat berkurang akibat sirkulasi yang tidak tertata dengan benar yang diakibatkan beberapa faktor yaitu tidak jelasnya sirkulasi dan tidak adanya hirarki sirkulasi, yakni pembagian ruang dan fungsi ruang antara sirkulasi pejalan kaki, pedagang kaki lima, perparkiran, dan sirkulasi kendaraan bermotor.

Tingkat suatu sirkulasi sangat baik jika sirkulasi dalam ruang dapat mengatur ruang sirkulasi antara pejalan kaki, parkir, dan arus kendaraan bermotor.

Menurut Francis D.K. Ching (1993), alur sirkulasi dapat diartikan sebagai "tali" yang mengikat ruang-ruang suatu bangunan atau suatu deretan ruang-ruang dalam maupun luar, menjadi saling berhubungan. Oleh karena itu kita bergerak dalam waktu melalui suatu tahapan ruang.

\section{b. Iklim dan Kekuatan Alam}

Iklim atau Kekuatan alam merupakan keadaan atmosfer pada suatu tempat dan waktu tertentu, biasanya diperhitungkan pada kondisi harian.Unsur-unsur iklim terdiri dari temperature, angin, tekananan udara, curah hujan dan kelembapan udara.

\section{c. Kebisingan}

Faktor yang mempengaruhi kenyamanan akibat kebisingan adalah suara bising dari kendaraan bermotor.Suara bising kendaraan bermotor atau alat transportasi pada suatu jalan mungkin dapat diatasi dengan penanaman pepohonan sebagai buffer, Kebisingan adalah bunyi yang tidak dikehendaki karena tidak sesuai konteks ruang dan waktu sehingga dapat menimbulkan gangguan terhadap kenyamanan dan kesehatan manusia.

\section{d. Aroma dan Bau-bauan}

Aroma atau bau-bauan yang tidak sedap bisa terjadi karena beberapa sebab, seperti bau yang keluar dari asap knalpot kendaraan, atau bak-bak sampah yang kurang terurus yang tersedia di sepanjang pinggir trotoar.

\section{e. Bentuk}

Bentuk elemen landscape furniture harus disesuaikan dengan ukuran standar manusia agar skala yang dibentuk mempunyai rasa nyaman (Hakim dan Utomo, 2003 : 190). Menurut vitivirus, tidak ada istilah bentuk.Bentuk bagi vitivurus, bila mau di kaitkan dengan fungsi/utilitas tentunya merupakan gabungan antara firmitas (thecnic) dengan venusitas (beauty/delight). 


\section{f. Keamanan}

Manusia memiliki jenjang kebutuhan, yang salah satunya adalah safety need. Safety need merupakan kebutuhan manusia yang berkaitan dengan keselamatan atau keamanan, supaya dirinya merasa terlindungi dari setiap gangguan. Sedangkan Hakim dan Utomo (2003 : 190) mengemukakan bahwa keamanan merupakan masalah yang mendasar, karena masalah ini dapat menghambat aktivitas yang dilakukan.

\section{g. Kebersihan}

Daerah yang terjaga kebersihannya akan menambah daya tarik khusus, selain menciptakan rasa nyaman serta menyenangkan orang-orang yang menggunakan Ruang Terbuka. Kebersihan lingkungan menjadi salah satu faktor utama demi berlangsungnya hidup yang bersih, sehat, dan nyaman.

\section{h. Keindahan}

Keindahan suatu ruang perlu diperhatikan secara serius untuk memperoleh suasana kenyamanan. Menurut Menurut Leo Tolstoy ( 2002) Keindahan adalah suatu yang dapat mendatangkan rasa yang menyenangkan bagi yang melihat dengan mata.

Ada dua teori tentang keindahan, yaitu yang bersifat subyektif dan obyektif.

- Keindahan subyektif ialah keindahan yang ada pada mata yang memandang

- Keindahan obyektif ialah menempatkan keindahan pada benda yang dilihat.

Berdasarkan Tinjauan Teoritis, dapat disimpulkan Faktor-Faktor Kenyamanan sebagai berikut :

\begin{tabular}{|c|c|c|}
\hline VARIABEL & KESIMPULAN & INDIKATOR \\
\hline \multirow{5}{*}{$\begin{array}{l}\text { Sirkulasi } \\
\text { D.K. Ching (1993) }\end{array}$} & - Saling berhubungan baik dengan fungsi & - Penghubung Ruang \\
\hline & - Menambah estetika ruang & - Sirkulasi Ruang \\
\hline & $\begin{array}{l}\text { - Kedekatan jarak membantu dalam } \\
\text { mengakses sirkulasi }\end{array}$ & $\begin{array}{l}\text { - Efesiensi Jarak } \\
\text { Pencapaian }\end{array}$ \\
\hline & - Membantu dalam proses perjalan & $\begin{array}{l}\text { - Efesiensi Waktu } \\
\text { Pencapaian }\end{array}$ \\
\hline & - Fungsi utama sebagai alat komunikasi & - Elemen Sirkulasi \\
\hline \multirow{5}{*}{$\begin{array}{l}\text { Iklim atau Kekuatan } \\
\text { alam } \\
\text { Syarif Hidayat (2011) }\end{array}$} & $\begin{array}{l}\text { - Temperatur dimuka bumi tidaklah sama tiap } \\
\text { saat }\end{array}$ & - Temperatur \\
\hline & $\begin{array}{l}\text { - Tekanan udara pada berbagai wilayah di } \\
\text { muka bumi tidak sama. }\end{array}$ & - Angin \\
\hline & $\begin{array}{l}\text { - Tekana udara rendah dibawah } 1013 \text { mb dan } \\
\text { tinggi di atas } 1013 \mathrm{mb} \text {. }\end{array}$ & - Tekanan Udara \\
\hline & - Curah hujan mempengaruhi banyak faktor & - Curah Hujan \\
\hline & $\begin{array}{l}\text { - Kandungan uap air di atmosfer secara rata- } \\
\text { rata cendrung konstan }\end{array}$ & - Kelembapan \\
\hline \multirow[t]{2}{*}{$\begin{array}{l}\text { Kebisingan } \\
\text { D.K. Ching (1993) }\end{array}$} & $\begin{array}{l}\text { - Kebisingan luas, kebisingan sempit, } \\
\text { kebisingan putus-putus, impulsive dan } \\
\text { impulsive terputus-putus }\end{array}$ & - Jenis Kebisingan \\
\hline & $\begin{array}{l}\text { - Kebisingan dari satu titik dan kebisingan dari } \\
\text { sumber yang bergerak }\end{array}$ & - Sumber Kebisingan \\
\hline
\end{tabular}




\begin{tabular}{|c|c|c|}
\hline Aroma atau Bau-bauan & $\begin{array}{l}\text { - Bau-bauan berasal dari banyak faktor } \\
\text { lingkungan dan kebiasaan }\end{array}$ & - Penyebab Bau-bauan \\
\hline \multirow[t]{4}{*}{$\begin{array}{l}\text { Bentuk } \\
\text { (Lang, 1987) }\end{array}$} & $\begin{array}{l}\text { - Bentuk dapat dikenali karena ia memiliki ciri- } \\
\text { ciri visual }\end{array}$ & - Ciri-ciri visual bentuk \\
\hline & $\begin{array}{l}\text { - Apa yang kita lihat menurut pengaruh atau } \\
\text { pengalaman sebelumnya }\end{array}$ & - Ekspresi Bentuk \\
\hline & $\begin{array}{l}\text { - Menurut interpretasi psikologi dari Teor } \\
\text { Gestalt tentang proses persepsi visual }\end{array}$ & - Teori tentang Ekspresi \\
\hline & $\begin{array}{l}\text { - Fungsi dan bentuk memang diperlukan } \\
\text { untuk menjelaskan arsitektur }\end{array}$ & - Keterkaitan Fungsi \\
\hline \multirow{3}{*}{$\begin{array}{l}\text { Keamanan } \\
\text { Hakim dan } \\
\text { Utomo(2003) }\end{array}$} & Pervasiveness (insidensi) & - Karakteristik Keamanan \\
\hline & $\begin{array}{l}\text { Perception (persepsi) } \\
\text { Management (pengaturan) }\end{array}$ & \\
\hline & $\begin{array}{l}\text { - Usia, gaya hidup, status mobilisasi, } \\
\text { gangguan sensori persepsi, tingkat } \\
\text { kesadaran, status emosional, kemampuan } \\
\text { komunikasi }\end{array}$ & $\begin{array}{l}\text { - Faktor-faktor yang } \\
\text { Mempengaruhi }\end{array}$ \\
\hline $\begin{array}{l}\text { Kebersihan } \\
\text { Soekidjo (2006) }\end{array}$ & $\begin{array}{l}\text { - Keberhasilan suatu ruang berdasarkan } \\
\text { kebersihan }\end{array}$ & - Manfaat Kebersihan \\
\hline \multirow[t]{2}{*}{$\begin{array}{l}\text { Keindahan } \\
\text { Vitruvius Polio }\end{array}$} & $\begin{array}{l}\text { Keindahan yang ada pada mata yang } \\
\text { memandang }\end{array}$ & - Keindahan subjektif \\
\hline & $\begin{array}{l}\text { - menempatkan keindahan pada benda yang } \\
\text { dilihat }\end{array}$ & - Keindahan Objektif \\
\hline
\end{tabular}

\section{Metode Penelitian}

Berdasarkan kerangka teoritis, model penelitian yang dirancang untuk memperlihatkan hubungan antara Persepsi penghuni terhadap kenyamanan beraktivitas diruang terbuka perumahan.

Metode penelitian ini menggunakan metode penelitian deskriptif kualitatif. Penelitian Deskriptif merupakan penelitian yang dilakukan untuk mengetahui nilai variabel mandiri, baik satu variabel atau lebih (independen) tanpa membuat perbandingan atau menghubungkan dengan variabel yang lain. Penelitian Kualitatif adalah penelitian ilmiah yang sistematis terhadap bagian-bagian dan fenomena serta hubungan-hubungannya.

\section{Metode Pengumpulan Data}

Berikut ini rancangan penelitian yang berbasis pada metodologi penelitian deskriptif kualitatif yang akan dilakukan :

\section{Populasi Dan Sampel}

\section{A. Populasi}

Menurut sugiyono 2013, Populasi adalah wilayah generalisasi yang terdiri atas objek/subjek yang mempunyai kualitas dan karakteristik tertentu yang ditetapkan oleh peneliti untuk dipelajari dan ditarik kesimpulannya. Pada penelitian ini yang menjadi populasi adalah Penghuni Perumahan Debang Taman Sari jalur-jalur pedestrian di gated 
community Kecamatan Medan Selayang. Di dalam perumahan Debang Taman Sari ini terdapat 8 tipe rumah hunian, antara lain Tipe tulip, Tipe anggrek dan teratai.

Keseluruhan hunian dalam perumahan Debang Taman Sari ini berjumlah 372 Unit. Pembangunan Perumahan Debang Taman Sari ini terdiri dari 2 tahap, tahap terakhir terdiri dari 3 tipe ,yaitu Tipe Katlya , Tipe Katlya Spesial dan Tipe Krisan.

\section{B. Sampel}

Menurut sugiyono 2013, sampel adalah bagian dari jumlah karakteristik yang dimiliki oleh populasi tersebut. Metode sampel dalam penelitian ini adalah dengan cara purposive sample, yang bertujuan bagi kedalaman pada penghayatan objek penelitian karena kondisi dan metode penelitian ini dilakukan akibat keterbatasan waktu dan tenaga. Penelitian ini terikat oleh waktu.Rencana Jumlah sampel yaitu 10 persen atau sekitar 100 orang dari jumlah penghuni perumahan.

\section{Proses Pengumpulan Data}

Metoda pengumpulan data yang digunakan melalui tahap observasi yang bertujuan untuk mengumpulkan permasalahan yang ada dan menentukan sejumlah variabel.

\section{Teknik Sampling}

Teknik sampling ini digunakan untuk menentukan jumlah sampel dari sejumlah populasi yang akan diteliti. Populasi sampling yang digunakan adalah penghuni Perumahan Debang Taman Sari Medan. Jumlah sampel yang akan diambil, dihitung berdasarkan rumus slovin dalam Sudrajat (2002) sebagai berikut.

Jumlah populasi yang dipakai adalah jumlah penduduk Perumahan Debang Taman Sari Medan sebanyak 1.115 jiwa, dengan tingkat kesalahan $10 \%$ maka diperoleh besarnya sampel minimal 92 orang.

\section{Kriteria Penilaian Penelitian}

Dalam penelitian ini, kriteria yang akan digunakan ada 2 variabel dan 2 Indikator yang akan menjadi tolak ukur dalam penelitian ini untuk mencapai tujuan penelitian yaitu sebagai berikut :

Tabel 1. Kriteria Penilaian Penelitian

Sumber : Analisis Penelitian 2016

\begin{tabular}{|c|l|l|}
\hline \multicolumn{2}{|c|}{ Kriteria } \\
\hline Variabel & PERSEPSI penghuni & $\begin{array}{l}\text { KENYAMANAN beraktivitas diruang } \\
\text { terbuka Perumahan }\end{array}$ \\
\hline Indikator & $\begin{array}{l}\text { Usia, status, kependudukan di perumahan } \\
\text { Debang Taman Sari Medan. }\end{array}$ & $\begin{array}{l}\text { Sirkulasi, Iklim, Kebisingan, Aroma, } \\
\text { Bentuk, Keamanan, Kebersihan dan } \\
\text { Keindahan. }\end{array}$ \\
\hline
\end{tabular}

Kriteria, Variabel dan indikator yang pertaman menggunakan kata Persepsi yang menyangkut identitas masyarakat yaitu berupa usia, status dan kependudukan di Perumahan Debang Taman Sari Medan. Dalam variabel dan indikator penilaian ada 16 variabel, yaitu sebagai berikut :

Tabel 2. Variabel dan Indikator Persepsi

Sumber : Analisa Penelitian 2015

\begin{tabular}{|l|l|r|}
\hline No & Variabel & Indikator Persepsi \\
\hline
\end{tabular}




\begin{tabular}{|c|c|c|}
\hline 1. & Identitas Penghuni & $\begin{array}{ll}\text { 1. } & \text { Usia } \\
\text { 2. } & \text { Jenis Kelamin } \\
\text { 3. } & \text { Status Kependudukan } \\
\text { 4. } & \text { Lama Tinggal }\end{array}$ \\
\hline 2. & $\begin{array}{l}\text { Kunjungan Ke Ruang Terbuka } \\
\text { Perumahan Debang Taman Sari }\end{array}$ & $\begin{array}{l}\text { 5. Pada saat kapan kunjungan } \\
\text { 6. Waktu kunjungan } \\
\text { 7. Lamanya kunjungan } \\
\text { 8. Dengan siapa kunjungan } \\
\text { 9. Banyaknya kunjungan } \\
\text { 10. Lama perjalan ke ruang terbuka } \\
\text { 11. Kendalam dalam kunjungan } \\
\text { 12. Pendapat tentang Ruang terbuka perumahan } \\
\text { Debang taman sari. } \\
\text { 13. Harapan Ruang terbuka perumahan Debang taman } \\
\text { sari. }\end{array}$ \\
\hline
\end{tabular}

Kriteria, variabel dan indikator yang dipakai adalah dengan menggunakan teori The Project for public space, 1999 ( Carmona et al.2003:100), tentang atribut kunci untuk ruang terbuka yang berhasil. Dalam penilaian ini ada 8 variabel yang akan digunakan untuk mengukur tingkat Kenyamanan suatu ruang terbuka.

Tabel 3. Skala penilaian Variabel dan Indikator Kenyamanan Beraktivitas Sumber : Analisis Penelitian 2016

\begin{tabular}{|c|c|c|c|}
\hline No & Kriteria & Variabel & Indikator Kenyamanan \\
\hline \multirow{5}{*}{1.} & \multirow{5}{*}{ Sirkulasi } & 1. Penghubung Ruang & 1. Tersedianya Penghubung ruang yang Jelas \\
\hline & & 2. $\quad$ Sirkulasi Ruang & 2. Adanya Sirkulasi Ruang yang mudah diakses \\
\hline & & 3. Jarak Pencapaian & 3.Kemudahan jarak pencapaian \\
\hline & & $\begin{array}{l}\text { 4. Efesiensi Waktu } \\
\text { Pencapaian }\end{array}$ & 4.Tercapainya Efesiensi waktu pencapaian \\
\hline & & 5. $\quad$ Elemen Sirkulasi & 5.Terdapatnya Elemen Sirkulasi \\
\hline \multirow{5}{*}{2} & \multirow{5}{*}{$\begin{array}{l}\text { Iklim atau Kekuatan } \\
\text { alam }\end{array}$} & 1. Temperatur & 6.Terciptanya Temperatur yang nyaman \\
\hline & & 2. Angin & 7. Tingkat kecepatan angin yang tidak mengganggu \\
\hline & & 3. Tekanan Udara & 8. Tekanan udara yang tidak mengganggu aktivitas \\
\hline & & 4. Curah Hujan & 9.Adanya tempat penunjang saat hujan \\
\hline & & 5. Kelembapan & 10.Kelembapan udara yang tidak berubah-ubah \\
\hline \multirow{2}{*}{3} & \multirow{2}{*}{ Kebisingan } & 1.Jenis kebisingan & $\begin{array}{l}\text { 11.Banyaknya jenis kebisingan tidak } \\
\text { mengganggu aktivitas }\end{array}$ \\
\hline & & 2. Sumber kebisingan & $\begin{array}{l}\text { 12.Sumber kebisingan tidak terlalu dekat dengan } \\
\text { lokasi }\end{array}$ \\
\hline 4 & Aroma dan Bau-bauan & 1.Penyebab bau-bauan & $\begin{array}{l}\text { 13.Adanya lokasi khusus untuk sampah yang } \\
\text { menyebabkan aroma }\end{array}$ \\
\hline \multirow{2}{*}{5} & \multirow{2}{*}{ Bentuk } & 1. Ciri-ciri visual bentuk & 14.Bentuk mudah dikenali karena ciri-ciri visual \\
\hline & & 2. Ekspresi Bentuk & 15.Adanya permainan bentuk yang menarik \\
\hline
\end{tabular}




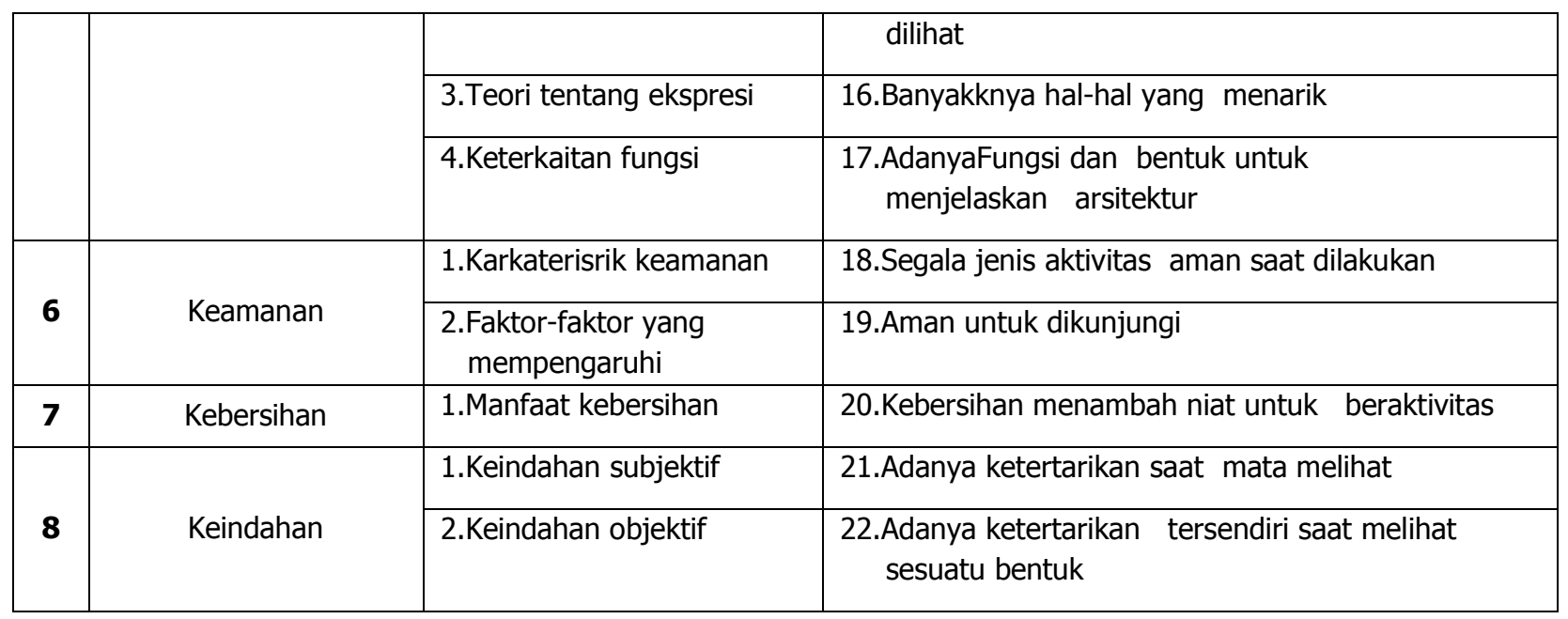

\section{Skala Pengukuran Penelitian}

Skala pengukuran adalah seperangkat aturan yang diperlukan untuk mendapatkan data kuantitatif data dari pengukuran suatu variabel (Sugiyono 2009). Skala pengukuran dalam penelitian ini dengan menggunakan 2 skala yaitu skala Nominal, dan Skala Likert. Skala Nominal adalah tingkat pengukuran yang paling sederhana, penelitian ini tidak melakukan pengukuran tetapi lebih pada mengkategorikan, memberi nama dan menghitung fakta-fakta dari objek yang diteliti. Skala Likert digunakan untuk mengukur sikap, pendapat, dan persepsi seseorang atau kelompok orang tentang fenomena sosial ini telah ditetapkan secara spesifik oleh peneliti, yang selanjutnya disebut variabel penelitian (Sugiyono,2009). Untuk skor yang digunakan adalah dimulai skor 1-5.

\section{Analisa dan Pembahasan}

\section{Tabulasi Frekuensi Data Identitas dan Pengalaman Pengunjung}

Persepsi Penghuni dibutuhkan untuk mendapatkan gambaran tentang sampel penelitian dalam penelitian. Dalam variabel Persepsi terdiri dari 21 variabel yang digunakan dan beberapa sub variabel Data Frekuensi Identitas Penghuni.

Data frekuensi menunjukkan usia 26-35 tahun sebagai frekuensi terbanyak dengan 21 orang ( 40,4\%). Untuk Variabel Jenis kelamin menunjukkan sub variabel perempuan sebagai frekuensi terbanyak dengan 29 orang (55,8\%). Untuk status pekerjaan frekuensi terbanyak ibu rumah tangga dengan 24 orang (46,2\%). Data Frekuensi Pengalaman Penghuni, Data frekuensi menunjukkan jika Hari libur (sabtu-minggu) sebagai frekuensi terbanyak dengan 24 orang $(46,2 \%)$ dan untuk variabel waktu kunjungan, frekuensi terbanyak yaitu pada sore hari (16.0018.00).

\section{Tabulasi Frekuensi Data Tingkat Kenyamanan Penghuni}

Tabel 4. Data Frekuensi Tingkat Kenyamanan Penghuni

\begin{tabular}{|c|c|c|c|c|c|c|c|c|c|c|c|c|c|}
\hline \multirow{2}{*}{ No } & \multirow{2}{*}{ Pertanyaan } & \multicolumn{10}{|c|}{ Kenyamanan } & \multirow{2}{*}{ Skor } & \multirow{2}{*}{ \%Skor } \\
\hline & & 1 & $\%$ & 2 & $\%$ & 3 & $\%$ & 4 & $\%$ & 5 & $\%$ & & \\
\hline 1. & $\begin{array}{l}\text { Nyamankah penghubung ruang } \\
\text { dari tempat anda ke lokasi } \\
\text { Taman }\end{array}$ & 0 & 0 & 0 & 0 & 39 & 75 & 11 & 21,2 & 2 & 3,9 & 171 & 65,8 \\
\hline 2. & $\begin{array}{l}\text { Nyamankah akses sirkulasi yang } \\
\text { anda lalui } \\
\text { dari tempat anda ke lokasi } \\
\text { Taman }\end{array}$ & 0 & 0 & 0 & 0 & 23 & 44,2 & 29 & 55,8 & 0 & 0 & 185 & 71,2 \\
\hline
\end{tabular}




\begin{tabular}{|c|c|c|c|c|c|c|c|c|c|c|c|c|c|}
\hline 3. & $\begin{array}{l}\text { Nyamankah anda ketika melalui } \\
\text { jalur sepanjang Taman }\end{array}$ & 0 & 0 & 3 & 5,8 & 13 & 25 & 36 & 69,2 & 0 & 0 & 189 & 72,7 \\
\hline 4. & $\begin{array}{l}\text { Bagaimanakah tanggapan anda } \\
\text { dengan } \\
\text { adanya Elemen Sirkulasi di } \\
\text { Taman }\end{array}$ & 0 & 0 & 0 & 0,0 & 41 & 78,8 & 11 & 21,2 & 0 & 0 & 167 & 64,2 \\
\hline 5. & $\begin{array}{l}\text { Bagaimanakah tanggapan anda } \\
\text { dengan } \\
\text { Elemen Sirkulasi dari pintu } \\
\text { Gerbang menuju Taman }\end{array}$ & 0 & 0 & 0 & 0,0 & 34 & 65,4 & 18 & 34,6 & 0 & 0 & 174 & 66,9 \\
\hline 6. & $\begin{array}{l}\text { Bagaimanakah menurut anda } \\
\text { Temperatur saat berada di } \\
\text { Taman }\end{array}$ & 0 & 0 & 3 & 5,8 & 33 & 63,5 & 16 & 30,8 & 0 & 0 & 169 & 65,0 \\
\hline 7. & $\begin{array}{l}\text { Bagaimanakah menurut anda } \\
\text { keadaaan angin saat berada di } \\
\text { Taman }\end{array}$ & 0 & 0 & 1 & 1,9 & 27 & 51,9 & 22 & 42,3 & 2 & 3,9 & 181 & 69,6 \\
\hline 8. & $\begin{array}{l}\text { Bagaimanakah menurut anda } \\
\text { Tekanan udara saat berada di } \\
\text { Taman }\end{array}$ & 0 & 0 & 3 & 5,8 & 44 & 84,6 & 5 & 9,62 & 0 & 0 & 158 & 60,8 \\
\hline 9. & $\begin{array}{l}\text { Bagaimanakah menurut anda } \\
\text { ketika terjadi hujan di Taman }\end{array}$ & 4 & 7,7 & 42 & 80,8 & 5 & 9,62 & 1 & 1,92 & 0 & 0 & 107 & 41,2 \\
\hline 10. & $\begin{array}{l}\text { Masih Nyamankah Taman } \\
\text { digunakan setelah selesai } \\
\text { hujan }\end{array}$ & 7 & 13,5 & 22 & 42,3 & 21 & 40,4 & 2 & 3,85 & 0 & 0 & 122 & 46,9 \\
\hline 11. & $\begin{array}{l}\text { Bagaimanakah pendapat anda } \\
\text { dengan } \\
\text { banyaknya jenis kebisingan } \\
\text { disekitar } \\
\text { Taman }\end{array}$ & 2 & 3,8 & 12 & 23,1 & 32 & 61,5 & 5 & 9,62 & 1 & 1,9 & 147 & 56,5 \\
\hline 12. & $\begin{array}{l}\text { Apakah anda tetap nyaman } \\
\text { kekita sumber } \\
\text { Kebisingan dekat dengan } \\
\text { Taman }\end{array}$ & 2 & 3,8 & 13 & 25,0 & 31 & 59,6 & 6 & 11,5 & 0 & 0 & 145 & 55,8 \\
\hline 13. & $\begin{array}{l}\text { Bagaimanakah pendapat anda } \\
\text { dengan } \\
\text { aroma di Taman }\end{array}$ & 0 & 0 & 11 & 21,2 & 41 & 78,8 & 0 & 0 & 0 & 0 & 145 & 55,8 \\
\hline 14. & $\begin{array}{l}\text { Nyamankah ksan visual tentang } \\
\text { Ekspresi bentuk dan fungsi di } \\
\text { Taman }\end{array}$ & 0 & 0 & 2 & 3,8 & 24 & 46,2 & 18 & 34,6 & 8 & $\begin{array}{c}15 \\
4\end{array}$ & 188 & 72,3 \\
\hline 15. & $\begin{array}{l}\text { Nyamankah anda melakukan } \\
\text { segala jenis } \\
\text { aktvitas disekitar Taman }\end{array}$ & 0 & 0 & 0 & 0,0 & 22 & 42,3 & 25 & 48,1 & 5 & 9,6 & 191 & 73,5 \\
\hline 16. & $\begin{array}{l}\text { Bagaimanakah pendapat anda } \\
\text { dengan } \\
\text { Kebersihan di Taman }\end{array}$ & 0 & 0 & 1 & 1,9 & 30 & 57,7 & 12 & 23,1 & 9 & $\begin{array}{c}17, \\
3\end{array}$ & 185 & 71,2 \\
\hline & $\sum \mathbf{X}$ & & & & & & & & & & & 2435 & \\
\hline
\end{tabular}




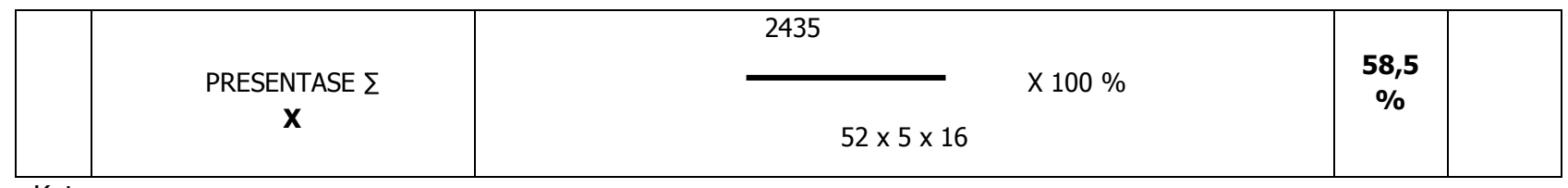

Ket :

$$
\text { Frekuensi suara terbanyak Sumber : Hasil Penelitian }
$$

\section{Hasil Penelitian}

Tanggapan Penghuni pada masing-masing indikator terhadap Kenyamanan beraktivitas diruang terbuka perumahan debang taman sari Medan, dapat digambarkan berdasarkan presentase akumulsai jumlah skor seluruh jawaban responden yang diperoleh dari indikator yang ada. Jumlah skor aktual dan skor ideal yang diperoleh adalah:

$$
\begin{aligned}
\text { Skor aktual } & =2435 \\
\text { Skor ideal } & =5 \times 52 \times 16 \\
& =4160
\end{aligned}
$$

Perbandingan skor aktual terhadap skor ideal di atas diperoleh presentase jumlah skor jawaban responden sebesar:

$$
\begin{aligned}
& \frac{\text { Skor Aktual }}{\text { Skor Ideal }} \times 100 \% \\
& \frac{2435}{4160} \times 100 \%=\mathbf{5 8 , 5 \%}
\end{aligned}
$$

Tanggapan Penghuni dari tabel di atas Persepsi Penghuni terhadap Kenyamanan beraktivitas diruang terbuka perumahan Debang Taman Sari Medan dapat dikatakan Sedang, karena nilai persentase dari keseluruhan jawaban pernyataan adalah sebesar $58,5 \%$ yang dimana berada pada rentang skor kuat yaitu $(0,40-0,59)$. Artinya Persepsi penghuni terhadap kenyamanan beraktivitas diruang terbuka perumahan debang taman sari Medan masih tergolong sedang.

Rentang dari nilai minimum dan maksimum tersebut kemudian dibagi lima untuk menentukan kriteria kualitas kenyamanan diruang terbuka perumahan debang taman sari medan. Apabila diklasifikasikan menjadi lima tingkatan maka rentang skor antara tingkatan dapat dihitung dengan cara sebagai berikut:

Nilai skor minimum : $1 \times 16 \times 52=832$

Nilai skor maksimum : $5 \times 16 \times 52=4.160$

Range $\quad: 4.160-832=3.328$

Jenjang range $: 3.328: 5=665,6$

Kategori akumulasi jumlah skor tanggapan responden yang terdiri dari 16 butir pernyataan mengenai Persepsi Penghuni Terhadap Kenyamanan Beraktivitas di Ruang Terbuka Perumahan dalam bentuk garis kontinum sebagai berikut:

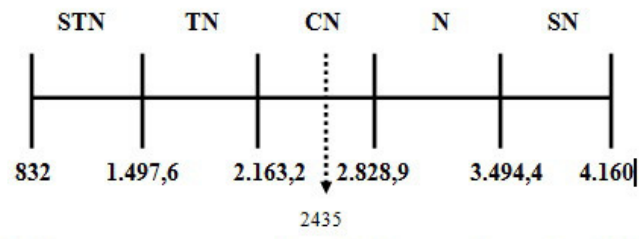


Jumlah skor tanggapan responden pada 16 pernyataan pada variabel Persepsi Penghuni Terhadap Kenyamanan Beraktivitas di Ruang Terbuka Perumahan Debang Taman Sari Medan dari seluruh pernyataan hasil skor adalah 2435.Jumlah tersebut terletak pada garis antara 2.163,2 dan 2.828,9 dalam kategori Sedang.Maka sebagian besar responden menyatakan Cukup Nyaman terhadap Kenyamanan Beraktivitas diruang Terbuka perumahan Debang Taman Sari Medan.Berdasarkan kategori tersebut maka dapat dikatahan bahwa Persepsi Penghuni Terhadap Kenyamanan Beraktivitas diruang Terbuka perumahan Debang Taman Sari Medan cukup nyaman.

\section{Kesimpulan dan Saran}

a. Pengunjung yang sering melakukan aktifitas di Ruang Terbuka Perumahan Debang Taman Sari Medan merupakan Perempuan 55,8 \% dengan usia rata-rata 25-35 tahun dengan perkerjaan lainnya (Ibu Rumah Tangga) . Waktu kunjungan yang sering dilakukan adalah pada sore hari (16.00-18.00) ketika hari libur (sabtuminggu).

b. Hasil penilaian persepsi penghuni pada variabel indikator pada tingkat kenyamanan menunjukkan makna nilai Sedang atau tergolong cukup nyaman. Hal tersebut menjadi penentu berhasilnya sebuah ruang Ruang Terbuka Perumahan khususnya Ruang terbuka Perumahan Debang Taman Sari Medan, yang seharusnya memiliki tingkat kenyamanan beraktivitas yang Sangat Nyaman, seperti akses sirkulasi yang baik, sarana penunjang saat terjadi hujan, kebisingan yang tidak mengganggu, aroma-aroma yang tidak mengganggu serta Kebersihan dan keindahan yang terkendali, sehingga nyaman untuk digunakan.

c. Kendala yang sering penghuni alami ketika sedang berada ruang terbuka perumahan Debang Taman Sari Medan yaitu tidak adanya sarana penunjang ketika terjadi hujan, sehingga tempat untuk berteduh memang tidak ada. Adapun harapan para penghuni Perumahan Debang Taman Sari Medan terhadap Ruang Terbuka Perumahan yaitu fasilitas didalamnya ditambah atau dilengkapi layaknya sebuah ruang terbuka yang memiliki perlengkapan aktivitas seperti fasilitas olahraganya, toilet, tempat berteduh dan tempat duduk yang nyaman serta sejuk.

\section{Saran}

Berdasarkan kesimpulan diatas, berikut ini adalah beberapa saran yang nantinya dapat dijadikan sebagai bahan pertimbangan bagi PT. Debang dan PT. Wika sebagai pengelola dalam kaitannya dengan persepsi penghuni terhadap kenyamanan beraktivitas diruang terbuka Perumahan. Adapun saran yang dapat peneliti sampaikan adalah :

- $\quad$ Adanyatempat berteduh saat terjadi hujan didalam ruang terbuka

- Kemudian fasilitas didalamnya dilengkapi seperti fasilitas olahraga, bangku duduk yang nyaman, toilet sehingga penghuni yang menggunakan ruang terbuka perumahan ini merasa nyaman.

\section{Daftar Pustaka}

Anggriani, Niniek, 2009, Pedestrian Ways dalam Perancangan Kota, 2009, Penerbit Humaniora

Ching, Francis D.K, 1993, Arsitektur Bentuk, Ruang dan Tatanan, Penerbit Erlangga

Pynkywati, Theresia; Aripin, Samsul; Iliyasa, Eri; Ningsih, Lelslye, 2014, Kajian Efisiensi Desain Sirkulasi Pada Fungsi Bangunan Mall dan Hotel BTC, Jurnal Reka Karsa No.1 Vol.2

Sugiyono, 2002, Metode Penelitian Administrasi, Bandung : Penerbit CV Alfabeta

Rainse, Usman; Abdi, 1998, Metodologi Penelitian Sosial dan Ekonomi, Penerbit Alfabeta

Http://www.landasanteori.com/2015/10/pengertian-perumahan-permukiman-menurut.html,Undang-UndangNomor 4 Tahun 1992 tentang Perumahan dan Permukiman, di akses pada tanggal 12 Januari 2016 